\title{
Two-Dimensional Molybdenum Carbide (MXene) with Divacancy Ordering for Brackish and Seawater Desalination via Cation and Anion Intercalation
}

Pattarachai Srimuk, J oseph Halim, J uhan Lee, Quanzheng Tao, J ohanna Rosén and Volker Presser

The self-archived postprint version of this journal article is available at Linköping University Institutional Repository (DiVA):

http:/ / urn.kb.se/ resolve?urn=urn:nbn:se:liu:diva-147137

N.B.: When citing this work, cite the original publication.

Srimuk, P., Halim, J., Lee, J ., Tao, Q., Rosén, J ., Presser, V., (2018), Two-Dimensional Molybdenum Carbide (MXene) with Divacancy Ordering for Brackish and Seawater Desalination via Cation and Anion Intercalation, ACS SUSTAINABLE CHEMISTRY and ENGINEERING, 6(3), 3739-3747. https:// doi.org/ 10.1021/ acssuschemeng.7b04095

Original publication available at:

https:// doi.org/ 10.1021/ acssuschemeng. 7b04095

Copyright: American Chemical Society http:// pubs.acs.org/ 


\title{
Two-dimensional molybdenum carbide (MXene) with divacancy ordering for brackish and sea water desalination via cation and anion intercalation
}

\author{
P. Srimuk, ${ }^{a, c}$ J. Halim, ${ }^{b}$ J. Lee, ${ }^{a, c}$ Q. Tao, ${ }^{b}$ J. Rosen, ${ }^{b,}{ }^{,}$and V. Presser ${ }^{a, c,}{ }^{*}$ \\ a INM - Leibniz Institute for New Materials, Campus D2 2, 66123 Saarbrücken, Germany \\ b Thin Film Physics, Department of Physics, Chemistry and Biology (IFM), Linköping University, SE-581 83 \\ Linköping, Sweden \\ c Department of Materials Science and Engineering, Saarland University, Campus D2 2, 66123 Saarbrücken, \\ Germany
}

* Corresponding authors' eMails: johanna.rosen@liu.se (JR) \& volker.presser@leibniz-inm.de (VP)

\begin{abstract}
Ion intercalation materials are emerging as a highly attractive class of electrodes for efficient energy water desalination. Most materials and concepts so far have focused on the removal of cations (especially sodium). Anion intercalation, however, remains still poorly investigated in water desalination. We present a study on $\mathrm{Mo}_{1.33} \mathrm{C}-\mathrm{MXene}$ capability of removing cations and anions and demonstrate the desalination performance in brackish water concentration and sea water concentration. $\mathrm{Mo}_{1.33} \mathrm{C}-\mathrm{MX}$ ene was prepared via acid treatment of the transition metal carbide MAX phase $\left(\mathrm{Mo}_{2 / 3} \mathrm{SC}_{1 / 3}\right)_{2} \mathrm{AlC}$. Binder-free electrodes were obtained by entangling MXene with carbon nanotubes and tested without the use of any ion exchange membrane at low ( $5 \mathrm{mM} \mathrm{NaCl})$ and high (600 mM NaCl) salt concentrations. Such electrodes showed a promising desalination performance of $15 \mathrm{mg} / \mathrm{g}$ in $600 \mathrm{mM} \mathrm{NaCl}$ with high charge efficiency up to $95 \%$. By Employing chemical online monitoring of the effluent stream, we separate the cation and anion intercalation capacity of the electrode material.
\end{abstract}

\section{Keywords}

Capacitive deionization; pseudocapacitance; water desalination; ion intercalation 


\section{Introduction}

Capacitive deionization (CDI) is a promising water treatment technology for the efficient energy desalination of saline media with a low salt content (esp. below $20 \mathrm{mM}$ ), such as brackish water. ${ }^{1}$ A conventional CDI cell accomplishes desalination of an in-flowing stream through ion electrosorption by the formation of an electrical double layer at fluid/solid interfaces between saline medium and the nanoporous carbon electrode. So far, various carbon materials have been explored as CDI electrodes, ${ }^{2}$ such as activated carbon, ${ }^{3-4}$ carbon cloth, ${ }^{5}$ carbon aerogel, ${ }^{6}$ or graphene ${ }^{7}$. However, values for the maximum salt removal capacities of optimized carbon nanomaterials seem to saturate at about $15-25 \mathrm{mg} / \mathrm{g}$ at a cell voltage of $1.2 \mathrm{~V}$. While novel cell designs try to overcome this limitation by use of ion exchange membranes $\mathrm{s}^{8-10}$ or suspension electrodes ${ }^{11-13}$, the search for electrode materials beyond carbon is actively pursued. ${ }^{14}$

Transitioning from conventional capacitive carbon for CDI to Faradaic materials allows ions intercalation in the crystal structure of the electrode. Some two-dimensional (2-D) materials such as transition metal dichalcogenides (TMDs) like $\mathrm{MoS}_{2}$ (Ref. ${ }^{15-16}$ ) or transition metal carbides (MXenes) $)^{17-19}$ may show the electric charge vs. potential profile of a capacitor and are thereby called pseudocapacitive..$^{20-21}$ By this way, the material accomplishes capacitor-like energy storage behavior albeit the energy storage process is fully Faradaic (ion intercalation); this is in contrast to the non-Faradaic process of ion electrosorption at electrically charged surfaces (conventional CDI and electrical double-layer capacitors). ${ }^{21-24}$ Such materials also allow to overcome the intrinsic preference of $\mathrm{CDI}$ operation for low molar concentrations: during ion electrosorption, charge is invested to expel ions with the same charge as the electrode (co-ions) and permselective desalination of only counter-ions (opposite charge than electrode) onsets after depletion of carbon nanopores from co-ions. Accordingly, high molar systems, such as supercapacitors, only show a change of the co-ion / counter-ion ratio, but fail to accomplish actual desalination of the surrounding saline medium. ${ }^{25-26}$ Intercalation materials, however, overcome this limitation in absence of ion exchange membranes by allowing removal permselective ion at high efficiency even at high molar strength (demonstrated up to $500 \mathrm{mM} \mathrm{NaCl}$; Ref. ${ }^{15}$ ). By this way, Faradaic deionization is a highly promising technology for energy efficient desalination of sea water or industrial waste water far above the salinity level of brackish water. ${ }^{14,27}$ 
Some novel concepts for electrochemical desalination with Faradaic electrode materials use asymmetric cell designs. The desalination battery, for example, relies on $\mathrm{Na}_{2} \mathrm{Mn}_{5} \mathrm{O}_{10}$, $\mathrm{Na}_{2} \mathrm{FePO}_{4}$, or $\mathrm{NaTi}_{2}\left(\mathrm{PO}_{4}\right)_{3}$ for sodium removal (via ion intercalation; Ref. ${ }^{28-30}$ ) and $\mathrm{Ag}$ or $\mathrm{BiOCl}$ for chloride removal (via conversion reaction; Ref. ${ }^{31-33}$ ). TMDs and MXenes, however, show the ability to insert cations or anions, but possibly with different uptake capacities. Yet, the slightly negative charge of many $M X e n e s^{34-35}$ makes the material less attractive to remove chloride and more effective for sodium removal. ${ }^{18} \mathrm{TMDs}$ like $\mathrm{MoS}_{2}$ have a point of zero charge closer to the fully discharged state and are more suitable for anion and cation removal. Compared to the removal of anions by a conversion reaction (like $\mathrm{Ag} / \mathrm{AgCl}$ ), ${ }^{31}$ their removal by intercalation remains much less explored. ${ }^{15,18}$ Anion intercalation, however, is well known for materials like graphite ${ }^{36-37}$ and very attractive for desalination technologies.

MXenes are a group of fast growing 2-D materials having high potential in many applications, ${ }^{19}$ such as energy storage (e.g., batteries and supercapacitors), ${ }^{38-39}$ energy conversion (e.g., solar cells and fuel cells), ${ }^{40-41}$ membranes, ${ }^{42-44}$ and water desalination ${ }^{45-46}$. MXene synthesis and processing can capitalize on existing ceramic manufacturing and is intensively explored for commercial application. ${ }^{47}$ Motivated by our recent study on the use of a MXene (namely: $\mathrm{Ti}_{3} \mathrm{C}_{2}$ MXene clay), ${ }^{18}$ we now introduce $\mathrm{Mo}_{1.33} \mathrm{C}$ for water desalination. This MXene originates from a family of 2-D atomic laminates with in-plane chemical order, coined $\mathrm{i}-\mathrm{MAX},{ }^{48}$ which after etching allows synthesis of a MXene with ordered divacancies. ${ }^{49}$ We provide first data of MXene at high molar strength from $5 \mathrm{mM}$ to $600 \mathrm{mM}$ and operate the 2-D material as binderfree electrodes in absence of any ion exchange membrane. By use of online monitoring of the chemical composition of the out-flowing water stream leaving the desalination cell with optical emission spectroscopy, we show to the ability of this MXene to intercalate sodium and chloride at the negative and positive electrode, respectively. We chose this MXene as the unique synthesis from the parent $\left(\mathrm{Mo}_{2 / 3} \mathrm{Sc}_{1 / 3}\right)_{2} \mathrm{AlC}$ with hydrofluoric acid yields a material with similar specific capacitance (unit: $\mathrm{F} / \mathrm{g}$ ) related to anion and cation intercalation. Other MXenes are known to show a significant chemical charge which offset the point of zero charge and modifies, thereby, the ability to uptake cations or anions. ${ }^{49}$ The point of zero charge of $\mathrm{Mo}_{1.33} \mathrm{C}$ MXene near $0 \mathrm{~V}$ should translate for a symmetric cell to a similar desalination capacity for anions and cations, when normalized to the number of intercalated ions. 


\section{Experimental description}

\section{Materials and synthesis}

The $\left(\mathrm{Mo}_{2 / 3} \mathrm{SC}_{1 / 3}\right)_{2} \mathrm{AIC}$ MAX phase was synthesized by following previous work (Ref. ${ }^{49}$ ). Briefly, graphite (99.99 \%, Sigma-Aldrich), molybdenum (99.99 \%, Sigma-Aldrich), aluminum (99.8\%, Sigma-Aldrich), and scandium (99.99\%, Stanford Advanced Material) were mixed in an agate mortar with the Mo:Sc:Al:C stoichiometric ratio of 1.33:0.67:1:1. The mixture was transferred into an alumina crucible and placed inside an argon flow furnace. The sample was heated to $1500{ }^{\circ} \mathrm{C}$ and held for $20 \mathrm{~h}$. After cooling the sample to room temperature in the furnace, a loosely packed MAX powder was obtained.

To prepare $\mathrm{Mo}_{1.33} \mathrm{C}$ MXene, the as-prepared MAX phase was crushed and sieved through a 450-mesh sieve (particle size $<30 \mu \mathrm{m}$ ). $1 \mathrm{~g}$ of sieved MAX was etched in $20 \mathrm{~mL}$ of concentrated HF (48 \%, Sigma-Aldrich) and continuously stirred for $24 \mathrm{~h}$. Thereafter, the suspension was filtered and dispersed in water. This process was repeated for five times to remove remaining acid and residual reaction products. The sample on the filter was then dried at room temperature for $12 \mathrm{~h}$. For exfoliation of MXene sheets, $100 \mathrm{mg}$ of etched MAX material was put in a centrifuge tube, containing $1 \mathrm{~mL}$ of tetrabutylammonium hydroxide (TBAOH). The solution was shaken manually for $5 \mathrm{~min}$ and centrifuged at $6000 \mathrm{rpm}$ for $5 \mathrm{~min}$ to remove the supernatant. The remaining TBAOH was removed by adding water and careful rinsing for three times.

\section{Material characterization}

X-ray diffraction (XRD) experiments were conducted employing a D8 Advance diffractometer

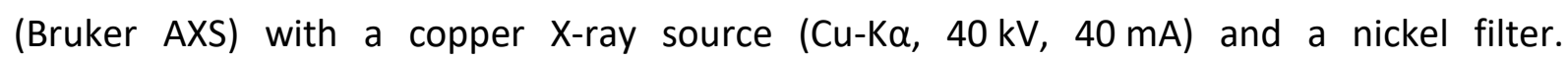
Measurements were conducted with a 2-D detector (VANTAC).

Scanning electron microscopy (SEM) was carried out on a JEOL JSM 7500F field emission scanning electron microscope (JEOL, Japan) operating at $3 \mathrm{kV}$. Energy dispersive X-ray spectroscopy (EDX) was carried out at $10 \mathrm{kV}$ in the system with an X-Max Silicon Detector from Oxford Instruments using AZtec software. Transmission electron microscopy (TEM) was carried out with a JEOL JEM-2100F system operating at $200 \mathrm{kV}$ in vacuum. Sample material was dispersed and sonicated in ethanol, and drop casted in copper grid with carbon film. 
Nitrogen gas sorption analysis (Supporting Information, Fig. S1) was conducted with a Quantachrome Autosorb iQ system. The samples were degassed at $200^{\circ} \mathrm{C}$ for $1 \mathrm{~h}$ and heated up to $300^{\circ} \mathrm{C}$. To remove volatile surface molecules, this temperature was kept for $20 \mathrm{~h}$ at a relative pressure of $0.1 \mathrm{~Pa}$. The nitrogen gas sorption analysis was carried out in liquid nitrogen at $-196{ }^{\circ} \mathrm{C}$. The relative pressure of nitrogen was increased from $5 \cdot 10^{-7}$ to 1.0 in 76 steps. The calculation of specific surface area (SSA) was performed with the Brunauer-Emmett-Teller equation (BET) in the linear low-pressure regime of the measured isotherms. As can be seen from Fig. S1, the $\mathrm{Mo}_{1.33} \mathrm{C}$ MXene and $\mathrm{Mo}_{1.33} \mathrm{C}-\mathrm{CNT}$ material is of very small external surface area (BET SSA of ca. 1 , and $\mathrm{x} \mathrm{m}^{2} / \mathrm{g}$ ).

\section{Electrode preparation}

We used a binder-free electrode for all electrochemical measurements (Supporting Information, Fig. S2) which was prepared as follows. $90 \mathrm{mg} \mathrm{Mo}{ }_{1.33} \mathrm{C}$ MXene flakes, achieving from TBAOH treatment, were mixed with $300 \mathrm{~mL}$ of water and sonicated while stirring in an ice-bate for $10 \mathrm{~min}$. In parallel, $5 \mathrm{mg}$ of multiwall carbon nanotubes (CNTs, Nonacyl NC7000) was added to $100 \mathrm{~mL}$ ethanol and sonicated for $20 \mathrm{~min}$. Then, the $\mathrm{Mo}_{1.33} \mathrm{C}$ MXene and CNTs mixtures were mixed and further sonicated for $10 \mathrm{~min}$. The $\mathrm{Mo}_{1.33} \mathrm{C}-\mathrm{CNT}$ dispersion was filtered through a porous spacer (glass fiber pre-filter, Millipore, compressed thickness of a single layer is $380 \mu \mathrm{m}$ ). Another $5 \mathrm{mg}$ of CNTs was dispersed in $100 \mathrm{~mL}$ ethanol and sonicated for $20 \mathrm{~min}$. The CNT dispersion was filtered through the previous $\mathrm{Mo}_{1.33} \mathrm{C}-\mathrm{CNT}$ electrode. The resulting electrode was dried overnight at $60^{\circ} \mathrm{C}$ in the oven. The total mass of CNT in the electrode was in the end 10 mass\%. The CNTs in the MXene layer prevent the restacking of the layer and avoid loss of MXene to the inflowing water stream during the later desalination application. The only-CNT-layer helps the electrical conductivity of the electrode. The overall small amount of CNTs has also only a small impact on the electrochemical performance (2$4 \mathrm{~F} / \mathrm{g}$ of the total electrode's capacitance may stem from the nanotubes).

\section{Electrochemical measurements}

Three-electrode (half-cell) electrochemical measurement were conducted in custom-build cell outlined in Ref. ${ }^{50}$. A disc of the $\mathrm{Mo}_{1.33} \mathrm{C}$-CNT electrode with diameter of $12 \mathrm{~mm}$ (mass loading of $1.2 \mathrm{mg}$ ) was used as the working electrode and graphite sheet (SGL carbon) was selected as a current collector for working and counter electrodes (diameter of $12 \mathrm{~mm}$ ). As a counter electrode, $15 \mathrm{mg}$ of activated carbon (YP80-F, Kuraray) with polytetrafluoroethylene (PTFE) 
was selected. The detail for carbon electrode preparation can be found in our previous work in Ref. ${ }^{51}$. For cell assembling, the graphite electrode was first placed in the cell following by carbon electrode, $13 \mathrm{~mm}$ diameter separator (GF/A, Whatmann), Mo1.33 C-CNT, and graphite current collector. The cell was tightly packed by spring loaded titanium piston. The $\mathrm{Ag} / \mathrm{AgCl}$ ( $3 \mathrm{M} \mathrm{KCl}, \mathrm{BASi}$ ) reference electrode was mounted at the side channel of the cell, where porous frit of reference electrode was close to the working and counter electrode. As an electrolyte, $1 \mathrm{M} \mathrm{NaCl}$ was filled into the cell via vacuum backfilling with a syringe.

The electrochemical measurement was conducted with a VMP300 potential stat /galvanostat (Bio-Logic). A cyclic voltammetry and galvanostatic cycling were employed with positive and negative polarization starting from $0 \mathrm{~V}$ vs. $\mathrm{Ag} / \mathrm{AgCl}$. For the positive polarization, $\mathrm{Mo}_{1.33} \mathrm{C}-\mathrm{CNT}$ electrode was limited potential at $+0.6 \mathrm{~V}$ vs. $\mathrm{Ag} / \mathrm{AgCl}$ while $-0.7 \mathrm{~V} \mathrm{vs}$. $\mathrm{Ag} / \mathrm{AgCl}$ was a limiting potential for negative polarization. For galvanostatic cycling technique, $\mathrm{Mo}_{1.33} \mathrm{C}-\mathrm{CNT}$ electrode was applied at different specific current $(0.1-10 \mathrm{~A} / \mathrm{g})$. The specific capacitance $\left(C_{\mathrm{sp}}\right)$ was calculated by using Eq. (1):

$C_{s p}=\frac{1}{U \cdot m} \int_{t_{1}}^{t_{2}} I d t$

Equation (1)

where $I$ is the applied current, $t_{2}-t_{1}$ is the time per half-cycle, $U$ is the potential different during polarization (excluding the $\mathrm{iR}$ drop), and $m$ is the total mass of the working electrode.

Two-electrode electrochemical characterization (full-cell configuration) was carried out using the same cell as three-electrodes (half-cell) experiment. Two $\mathrm{Mo}_{1.33} \mathrm{C}$-CNT electrodes with diameter of $12 \mathrm{~mm}$ (total mass $1.4 \mathrm{mg}$ ) were separated by a separator with $13 \mathrm{~mm}$ in diameter. Graphite sheets (12 mm diameter) were employed as current collector. After tightly assembling the cell, $1 \mathrm{M} \mathrm{NaCl}$ was injected to the cell by vacuum backfilling. This concentration was chosen to avoid any ion starvation during the experiment; for more information on the correlation between capacitance and ion concentration, see Ref. ${ }^{9}$. To record cyclic voltammograms, we scanned the cell voltage from 0 to $1 \mathrm{~V}$ with sweeping rate of $5 \mathrm{mV} / \mathrm{s}$. The cell was charged and discharged with different specific currents, ranging from $0.1 \mathrm{~A} / \mathrm{g}$ to $10 \mathrm{~A} / \mathrm{g}$ with cell voltage between 0 and $1 \mathrm{~V}$. To measure potential at zero charge, $\mathrm{ag} / \mathrm{AgCl}$ spectator reference was present in the cell. By this way, the individual potential of each electrode was measured during galvanostatic cycling experiment. The specific capacitance $C_{\mathrm{sp}}$ was calculated according to Ref. ${ }^{52}$. 


\section{Desalination measurements}

For desalination experiments, the electrode preparation was the same as electrode for electrochemical analysis. The binder-free $\mathrm{Mo}_{1.33} \mathrm{C}$-CNT electrodes were assembled in a flowby cell described in Ref. ${ }^{18}$. The CDI stack was built from graphite current collectors with attached to $\mathrm{Mo}_{1.33} \mathrm{C}-\mathrm{CNT}$ electrodes. The total mass of electrode including CNT was $300 \mathrm{mg}$ with a thickness of $5 \mu \mathrm{m}$ (Supporting Information, Fig. S1). Afterwards, the cell was tightly closed to avoid the leakage during measurement.

The electrochemical desalination measurements were carried out with two symmetric pairs of electrodes where no ion exchange membranes or binder were used. The total electrolyte flow rate was $15 \mathrm{~mL} / \mathrm{min}$. Desalination (charging) and salination (discharging) steps were carried out using constant potential mode with a cell voltage of $+0.8 \mathrm{~V}$ and regeneration was accomplished at $0 \mathrm{~V}$. Note that most $\mathrm{CDI}$ works with carbon electrodes use $1.2 \mathrm{~V}$ as the cell voltage; such high cell voltages were not suitable for the present electrode material per consideration of the electrochemical stability window. This is in alignment with our previous work on molybdenum disulfide. ${ }^{15}$ For all electrochemical operations, we used a VSP300 potentiostat/galvanostat (Bio-Logic) and the duration of each half-cycle was 40 min to ensure near-equilibrium conditions. All experiments were carried out with a concentration of $5 \mathrm{mM}$, $50 \mathrm{mM}$, or $600 \mathrm{mM} \mathrm{NaCl}$ solution in a $10 \mathrm{~L}$ electrolyte tank and the saline medium was deaerated by flushing nitrogen gas. This was done to limit the dissolved oxygen in the solution and allows comparison with the current CDI literature on carbon electrodes without ion exchange membranes. ${ }^{1}$ The salt removal capacity and the measured charge were defined per total mass of electrode material (i.e., $\mathrm{Mo}_{1.33} \mathrm{C}$ MXene and CNTs) and were calculated following our previous works (Ref. ${ }^{15,18}$ ).

\section{Online ICP-OES monitoring of the desalination process}

Two stacked electrode pairs containing $\mathrm{Mo}_{1.33} \mathrm{C}-\mathrm{CNT}$ were assembled in the $\mathrm{CDI}$ cell. The adsorption and desorption steps were conducted via chronoamperometry. During charging, constant voltage of $0.8 \mathrm{~V}$ was applied and held for $40 \mathrm{~min}$. Afterwards, the cell was discharged at a constant cell voltage of $0 \mathrm{~V}$ and held for $40 \mathrm{~min}$. For inductively coupled plasma optical emission spectroscopy (ICP-OES) experiments, the flow rate was $2.5 \mathrm{~mL} / \mathrm{min}$ to enhance the signal-noise ratio. The saline solution was $5 \mathrm{mM} \mathrm{NaCl}$ with a reservoir tank volume of $10 \mathrm{~L}$, which was flushed continuously with $\mathrm{N}_{2}$ gas to remove dissolved oxygen. To detect the 
effluent ion concentration, $2 \mathrm{~mL} / \mathrm{min}$ of solution was constantly extracted from the outlet stream of the cell by the peristatic pump of the system (ARCOS FHX22, SPECTRO Analytical Instruments). The online intensities from extracted sample were converted into concentration profiles. The ion removal capacity was calculated for sodium and for chlorine individually using Eq. (2):

Ion removal capacity $\left(\frac{m_{\text {ion }}}{m_{\text {electrode }}}\right)=\frac{v \cdot M_{\text {ion }}}{m_{\text {electrode }}} \int c d t$ Equation (2) where $v$ is flow rate $(2.5 \mathrm{~mL} / \mathrm{min}), M_{\text {ion }}$ is the molecular weight of ion species ( $\mathrm{Na:} 23 \mathrm{~g} / \mathrm{mol}$, $\mathrm{Cl}: 35.4 \mathrm{~g} / \mathrm{mol}), m$ is mass of either positive or negative electrode $(\mathrm{mg}), c$ is the ion concentration of outlet stream ( $\mathrm{mol} / \mathrm{L}$ ), and $t$ is ion removal time (min).

\section{Results and discussion}

$\mathrm{Mo}_{1.33} \mathrm{C}$ MXene was synthesized following the protocol published in previous work. ${ }^{49} \mathrm{After} \mathrm{HF}$ etching of the ternary metal carbide precursor $\left(\mathrm{Mo}_{2 / 3} \mathrm{Sc}_{1 / 3}\right)_{2} \mathrm{AIC}$ and tetrabutylammonium hydroxide $(\mathrm{TBAOH})$ intercalation, the resulting MXene shows wrinkle layers morphology (Fig. 1A) with a grain size larger than $20 \mu \mathrm{m}$. Thin-layer $\mathrm{Mo}_{1.33} \mathrm{C}$ MXene is shown in Fig. 1B, indicating successfully delamination of multilayer $\mathrm{Mo}_{1.33} \mathrm{C}$ MXene. Chemical analysis via energy dispersive X-ray spectroscopy (EDX) shows small intensity of Al and Sc (Fig. 1C), indicating that most of $\mathrm{Al}$ (A-layer) and in-plane Sc (part of the M-layer) were removed during acid treatment. Those atoms were replaced by F- and O- functional groups (Table 1). This is in good alignment with X-ray diffractogram in Fig. 1D, showing reflection of $\mathrm{Mo}_{1.33} \mathrm{C} \mathrm{MXene}$ particles, especially the (002)-reflection at $6.6^{\circ} 2 \theta$. Other reflections correlate to incompletely reacted MAX, for example, the prominent peak at $13.1^{\circ} 2 \theta$. A more detailed assignment of the different XRD peaks can be seen in Ref. ${ }^{49}$. The broad reflection at around $24-26^{\circ} 2 \theta$ originates from the carbon nanotubes (CNT) added during electrode manufacturing. Binder-free $\mathrm{Mo}_{1.33} \mathrm{C}$ CNT was fabricated by simple filtration of MXene and CNT dispersion through the glass fiber separator (Supplementary Information, Fig. S1). The total CNT content of 10 mass\% effectively avoided MXene re-stacking and washing-out of the MXene flakes during desalination operation (adopting the approach we used in our previous work on 2-D MoS $;$; Ref. ${ }^{15}$ ).

Prior to desalination testing, we carried out thorough electrochemical analysis with a threeelectrode configuration using $1 \mathrm{M} \mathrm{NaCl}$. This half-cell setup allows us to characterize the 
electrochemical response of the $\mathrm{Mo}_{1.33} \mathrm{C}-\mathrm{CNT}$ electrodes either during positive or negative potential polarization. A cyclic voltammogram (CV) of $\mathrm{Mo}_{1.33} \mathrm{C}-\mathrm{CNT}$ is shown in Fig. $2 \mathrm{~A}$. By sweeping the electrode potential from 0 to $+0.6 \mathrm{~V}$ vs. $\mathrm{Ag} / \mathrm{AgCl}$ and from 0 to $-0.7 \mathrm{~V} \mathrm{vs}$. $\mathrm{Ag} / \mathrm{AgCl}$ at a rate of $5 \mathrm{mV} / \mathrm{s}$ for each individual cell, we see a pronouncedly pseudocapacitive response in the form of slightly distort rectangular shapes. This resistive element in the response (resistive knee) stems from the limited kinetics of ion intercalation in between MXene sheets. The term pseudocapacitive ${ }^{21}$ identifies a capacitor-like electrical behavior which does not originate in ion electrosorption, but is caused by a Faradaic process. In case of MXene, ions intercalate between the atomic layers not selectively at a certain applied potential, but continuously as charge is applied. ${ }^{20}$ This gives rise to a linear correlation between charge and potential, as one would expect it for an ideal electrical double-layer capacitor. In a battery-like system, for comparison, we would see clear redox peaks during charging and discharging, associated with distinct intercalation states, phase transitions, or phase conversions. ${ }^{24}$

For stable cell operation, it is of high importance to determine the electrochemical stability window. As can be seen, the negative limit potential of this MXene is estimated to be $-0.4 \mathrm{~V}$ vs. $\mathrm{Ag} / \mathrm{AgCl}$ for the negative electrode and the positive limit potential of $+0.55 \mathrm{~V} v \mathrm{Ag} / \mathrm{AgCl}$ for positive electrode. To estimate specific capacitance of $\mathrm{Mo}_{1.33} \mathrm{C}-\mathrm{CNT}$ electrode, galvanostatic charge-discharge was conducted with specific current of $0.1-10 \mathrm{~A} / \mathrm{g}$. As shown in Fig. 2B, the maximum specific capacitance for the positive electrode is $150 \mathrm{~F} / \mathrm{g}$ at $0.1 \mathrm{~A} / \mathrm{g}$ while the maximum specific capacitance for the negative electrode is $155 \mathrm{~F} / \mathrm{g}$ at $0.1 \mathrm{~A} / \mathrm{g}$. The performance is stable and maintains ca. $90 \%$ of the initial specific capacitance after 100 galvanostatic charge/discharge cycles at $0.1 \mathrm{~A} / \mathrm{g}$ (Fig. 2C).

Operation of the full-cell shows a pseudocapacitive CV shape (Fig. 2D). The full cell yields a specific capacitance of $150 \mathrm{~F} / \mathrm{g}$ at $0.1 \mathrm{~A} / \mathrm{g}$ as determined by galvanostatic charge/discharge cycling (Fig. 2E). An onset of electrochemical decomposition is already indicated by the increase of irreversible current when exceeding a cell voltage of $0.8 \mathrm{~V}$ (Fig. 2D). This is further confirmed when tracing the potential of the negative and positive electrode by use of a $\mathrm{Ag} / \mathrm{AgCl}$ spectator reference (Fig. $2 \mathrm{~F}$ ): beyond a cell voltage of $0.8 \mathrm{~V}$, the cell potential at zero charge decreases from about $0 \mathrm{~V}$ vs. $\mathrm{Ag} / \mathrm{AgCl}$ to about $-0.2 \mathrm{~V}$ vs. $\mathrm{Ag} / \mathrm{AgCl}$. The loss of symmetric potential distribution between negative and positive electrode aligns with the emergence of irreversible Faradaic reactions (e.g., decomposition of surface termination group, HER, and OER). ${ }^{53}$ Therefore, we have limited the cell voltage for a symmetric cell (i.e., two $\mathrm{Mo}_{1.33} \mathrm{C}-\mathrm{CNT}$ 
electrodes with same size and mass loading) to $0 . \mathrm{V}$. This is the same value as recently found for $\mathrm{MoS}_{2}$-CNT electrodes ${ }^{15}$ and is significantly lower than most works on CDI by use of carbon electrodes (typically: 1.2 V). ${ }^{1,27}$

Desalination was benchmarked at $5 \mathrm{mM}, 50 \mathrm{mM}$, and $600 \mathrm{mM}$ aqueous $\mathrm{NaCl}$ solution to cover the range from brackish water $(<17 \mathrm{mM})$ to sea water ( $\sim 00 \mathrm{mM}=3.5 \%$ salinity). At all three concentrations, we see the characteristic charge/discharge $=$ desalination/salination pattern in the conductivity profiles of the outflowing stream (Fig. 3A-C). In alignment with our previous work, ${ }^{15}$ we see an increase in desalination capacity ( $\mathrm{NaCl}$ capacity) from $5 \mathrm{mg} / \mathrm{g}$ to about $15 \mathrm{mg} / \mathrm{g}$ when increasing the salinity from $5 \mathrm{mM}$ to $600 \mathrm{mM} \mathrm{NaCl}$ (all values normalized to the total mass of both electrodes). The increase of desalination capacity with by increasing salinity is a unique feature of desalination of Faradaic materials; in case of conventional CDI employing nanoporous carbon, the increasing amount of co-ion expulsion consumes an increasing charge and desalination capacity and charge efficiency drop drastically at a concentration above $50 \mathrm{mM}$. In our case, however, $\mathrm{Mo}_{1.33} \mathrm{C}$-CNT electrodes maintain a charge efficiency of ca. 75-97 \% over 40 desalination cycles at all concentration regimes (Fig. 3E). This high charge efficiency is also supported by the stable $\mathrm{pH}$ of outlet stream during desalination process with variations $\Delta \mathrm{pH}<0.5$. It is an important aspect of CDI and for desalination with Faradaic materials to precisely consider the upper and lower potential limit to avoid parasitic reactions, low charge efficiency, low salt removal capacity, and rapid performance loss. ${ }^{54}$

In a next step, we calculated the energy consumption per removed ion without considering the energy recovery or pumping energy following the procedure from our previous work. ${ }^{49} \mathrm{By}$ this way, we can derive quantitative data to estimate the energy consumption of the electrodes. The energy consumed during desalination was divided by the salt removal capacity. This yields the energy in $\mathrm{J} / \mathrm{mol}$ of $\mathrm{NaCl}$ which is divided by Boltzmann constant $\mathrm{k}$ $(2.48 \mathrm{~kJ} / \mathrm{mol})$ to obtain energy consumption in $\mathrm{kT}$. $\mathrm{Mo}_{1.33} \mathrm{C}-\mathrm{CNT}$ exhibit energy consumption of $21 \mathrm{kT}, 20.5 \mathrm{kT}$, and $17 \mathrm{kT}$ in $5 \mathrm{mM}, 50 \mathrm{mM}$, and $600 \mathrm{mM} \mathrm{NaCl}$, respectively (Fig. 3F). These values are slightly lower than other materials, for example, nickel hexacyanoferrate $(20 \mathrm{kT}$ in $20 \mathrm{mM} \mathrm{NaCl}$ ), 28 MWCNT $\mathrm{h}-\mathrm{V}_{2} \mathrm{O}_{5}$ (17.9 kT in $\left.600 \mathrm{mM} \mathrm{NaCl}\right),{ }^{55} \mathrm{MoS}_{2}-10 \mathrm{CNT}$ (24.6 kT in $500 \mathrm{mM}$ ), ${ }^{15}$ activated carbon (94.4 $\mathrm{kT}$ in $500 \mathrm{mM} \mathrm{NaCl}$ using a multi-channel membrane CDI unit), ${ }^{9,} 56$ and activated carbon with ion exchange membrane (20-24 kT in 5-200 mM NaCl$)^{25}$. Clearly, desalination using $\mathrm{Mo}_{1.33} \mathrm{C}$ consumes less energy as compared to the use of carbon electrodes (even when the latter are operated in conjunction with ion exchange membranes). 
For comparison: the energy consumption per ion removal of seawater reverse osmosis is still lower with $7.5 \mathrm{kT}$ for $50 \%$ water removal. ${ }^{57}$

The average desalination rates of our system and selected other works are presented in Table 2. One could see that desalination rate of intercalation materials is typically slower than that of conventional CDI. For instance, porous carbon electrode exhibits a rate of $6.5 \mu \mathrm{g} / \mathrm{g} / \mathrm{s}$ operating in $5 \mathrm{mM} \mathrm{NaCl}$ and $0.8 \mathrm{~V}$ whereas intercalation materials like $\mathrm{Mo}_{1.33} \mathrm{C}$ MXene shows a desalination rate of $2.1 \mu \mathrm{g} / \mathrm{g} / \mathrm{s}$ operating in $5 \mathrm{mM} \mathrm{NaCl}$ and $0.8 \mathrm{~V}$. Yet, for a direct comparison and to investigate the intrinsic limitations of different systems, cell parameters (like electrode thickness and mass loading) must be carefully kept constant since thin electrodes, for example, skew the desalination rate towards higher values. ${ }^{58}$

Per the extremely small outer surface area of MXene (ca. $1 \mathrm{~m}^{2} / \mathrm{g} ; 30 \mathrm{~m}^{2} / \mathrm{g}$ for $\mathrm{Mo}_{1.33} \mathrm{C}-\mathrm{CNT}$, Supplementary Information, Fig. S1) and assuming an areal capacity of around $0.1 \mathrm{~F} / \mathrm{m}^{2}, 52,59$ the non-Faradaic contribution to the total measured specific capacitance is negligible (ca. $2 \%$, that is: $3 \mathrm{~F} / \mathrm{g}$ of $150 \mathrm{~F} / \mathrm{g}$ ). Thereby, the only mechanism by which the significant desalination performance can be accomplished through intercalation between the MXene layers. Our previous studies have shown changes in the lattice distances for $\mathrm{Ti}_{3} \mathrm{C}_{2}-\mathrm{MXene}$ and $\mathrm{MoS}_{2}-\mathrm{CNT}$ electrodes. ${ }^{15,18}$ Also, the electrochemical data clearly show that both positive and negative polarization follow a pseudocapacitive pattern. The only way to explain this behavior is by cation intercalation in the negatively polarized electrode and by anion intercalation in the positively polarized electrode. To further corroborate this ion storage mechanism and to separate the anion and cation removal capacity, we have analyzed the effluent stream's chemical composition with online monitoring with an inductively coupled plasma optical emission spectroscopy (ICP-OES) system. This technique is applied for the first time to an intercalation electrode material and for the study of the anion concentration profiles; so far, ICP-OES studies have only looked at the cation removal and have remained limited to nanoporous carbon electrodes and conventional CDI. ${ }^{60-61}$

As can be seen from the concentration profiles for sodium (Fig. 4A) and chlorine (Fig. 4B), both follow the concentration profiles expected for electrochemical desalination (Fig. 3A-C). Considering the different molar masses, the removal capacity is $4.5 \mathrm{mg} / \mathrm{g}_{(-)}$for $\mathrm{Na}_{+}$(normalized to the mass of the negative electrode) and $7.5 \mathrm{mg} / \mathrm{g}_{(+)}$for $\mathrm{Cl}^{-}$(normalized to the mass of the positive electrode), as determined for $5 \mathrm{mM} \mathrm{NaCl}$. On average, this computes to a $\mathrm{NaCl}$ 
removal capacity of $4.8 \mathrm{mg} / \mathrm{g}$ normalized to the mass of both electrodes. This value agrees with the desalination capacity determined by conventional conductivity measurements ( $5 \mathrm{mg} / \mathrm{g}$ normalized to the mass of both electrodes; Fig. 3D).

\section{Conclusions}

Our work provides first data for the use of $\mathrm{Mo}_{1.33} \mathrm{C}$ MXene as sodium ions and chloride ions intercalation via inductive couple plasma optical emission spectroscopy. This MXene accomplishes desalination with ease at low or high salt concentration, ranging from low to high salinity (i.e., from brackish water to seawater). By entangling MXene within a CNT network, effective binder-free electrodes are obtained with a promising salt removal capacity of $5 \mathrm{mg} / \mathrm{g}, 9 \mathrm{mg} / \mathrm{g}$, and $15 \mathrm{mg} / \mathrm{g}$ in $5 \mathrm{mM}, 50 \mathrm{mM}$, and $600 \mathrm{mM} \mathrm{NaCl}$, respectively; in all cases, we measured a very high charge efficiency up to $97 \%$. The energy consumption during ion removal in sea water concentration $(600 \mathrm{mM} \mathrm{NaCl})$ is low $(17 \mathrm{kT})$, which would be impossible to accomplish with conventional carbon electrodes operated with capacitive deionization. These excellent performance metrics were obtained in absence of any ion exchange membranes, which are major cost-drivers for present-day CDI units. In particular, the compatibility of MXene for desalination of saline media with high molar strength opens new application areas, such as the generation of drinking water from sea water. 


\section{Acknowledgements}

The authors thank Prof. Eduard Arzt (INM) for his continuing support. S.P. acknowledges financial support by the German Academic Exchange Service (DAAD award number 91579066). JR acknowledges funding from the Swedish Research Council (642-2013-8020), the Swedish Foundation for Strategic Research (SSF) through the Synergy Grant FUNCASE, and from the Knut and Alice Wallenberg (KAW) Foundation for a Fellowship Grant and Project funding (KAW 2015.0043). We thank Dr. Choudhury, Mr. Zeiger, Mr. Fleischmann, and Ms. Tolosa for technical assistance (all at INM).

\section{Supporting Information}

Gas sorption isotherm data, scanning electron microscopy cross-section. 


\section{References}

1. Suss, M. E.; Porada, S.; Sun, X.; Biesheuvel, P. M.; Yoon, J.; Presser, V., Water desalination via capacitive deionization: what is it and what can we expect from it? Energy Environ. Sci. 2015, 8 (8), 2296-2319.

2. Liu, Y.; Nie, C. Y.; Liu, X. J.; Xu, X. T.; Sun, Z.; Pan, L. K., Review on carbon-based composite materials for capacitive deionization. RSC Adv. 2015, 5 (20), 15205-15225.

3. Guyes, E. N.; Simanovski, A.; Suss, M. E., Several orders of magnitude increase in the hydraulic permeability of flow-through capacitive deionization electrodes via laser perforations. RSC Adv. 2017, 7 (34), 21308-21313.

4. Wang, Z.; Yan, T. T.; Chen, G. R.; Shi, L. Y.; Zhang, D. S., High Salt Removal Capacity of MetalOrganic Gel Derived Porous Carbon for Capacitive Deionization. ACS Sustainable Chem. Eng. 2017, 5 (12), 11637-11644.

5. Kim, C.; Srimuk, P.; Lee, J.; Fleischmann, S.; Aslan, M.; Presser, V., Influence of pore structure and cell voltage of activated carbon cloth as a versatile electrode material for capacitive deionization. Carbon 2017, 122 (1), 329-335.

6. Suss, M. E.; Baumann, T. F.; Bourcier, W. L.; Spadaccini, C. M.; Rose, K. A.; Santiago, J. G.; Stadermann, M., Capacitive desalination with flow-through electrodes. Energy Environ. Sci. 2012, 5 (11), 9511-9519.

7. Xu, X.; Sun, Z.; Chua, D. H. C.; Pan, L., Novel nitrogen doped graphene sponge with ultrahigh capacitive deionization performance. Sci. Rep. 2015, 5, 11225.

8. Biesheuvel, P. M.; van der Wal, A., Membrane capacitive deionization. J. Membr. Sci. 2010, 346 (2), 256-262.

9. Kim, C.; Lee, J.; Srimuk, P.; Aslan, M.; Presser, V., Concentration-gradient multi-channel flow stream membrane capacitive deionization cell for ultra-high desalination capacity of carbon electrodes. ChemSusChem 2017, 10 (24), 4914-4920.

10. Gu, X.; Deng, Y.; Wang, C., Fabrication of Anion-Exchange Polymer Layered GrapheneMelamine Electrodes for Membrane Capacitive Deionization. ACS Sustainable Chem. Eng. 2017, 5 (1), 325-333.

11. Doornbusch, G. J.; Dykstra, J. E.; Biesheuvel, P. M.; Suss, M. E., Fluidized bed electrodes with high carbon loading for water desalination by capacitive deionization. J. Mater. Chem. A 2016, 4 (10), 3642-3647.

12. Jeon, S. I.; Park, H. R.; Yeo, J. G.; Yang, S.; Cho, C. H.; Han, M. H.; Kim, D. K., Desalination via a new membrane capacitive deionization process utilizing flow-electrodes. Energy Environ. Sci. 2013, 6 (5), 1471-1475.

13. Porada, S.; Weingarth, D.; Hamelers, H. V. M.; Bryjak, M.; Presser, V.; Biesheuvel, P. M., Carbon flow electrodes for continuous operation of capacitive deionization and capacitive mixing energy generation. J. Mater. Chem. A 2014, 2 (24), 9313-9321.

14. Suss, M. E.; Presser, V., Electrochemical water desalination with energy storage electrode materials. Joule 2018, DOI:10.1016/j.joule.2017.12.010.

15. Srimuk, P.; Lee, J.; Fleischmann, S.; Choudhury, S.; Jäckel, N.; Zeiger, M.; Kim, C.; Aslan, M.; Presser, V., Faradaic deionization of brackish and sea water via pseudocapacitive cation and anion intercalation into few layered molybdenum disulfide. J. Mater. Chem. A 2017, 5 (30), 15640-15649.

16. Xing, F.; Li, T.; Li, J.; Zhu, H.; Wang, N.; Cao, X., Chemically Exfoliated $\mathrm{MoS}_{2}$ for Capacitive Deionization of Saline Water. Nano Energy 2017, 31, 590-595.

17. Naguib, M.; Kortoglu, M.; Presser, V.; Lu, J.; Hultman, L.; Niu, J.; Heon, M.; Gogotsi, Y.; Barsoum, M. W., Two-dimensional nanocrystals produced by exfoliation of $\mathrm{Ti}_{3} \mathrm{AlC}_{2}$. Adv. Mater. 2011, 23 (37), 4248-4253.

18. Srimuk, P.; Kaasik, F.; Krüner, B.; Tolosa, A.; Fleischmann, S.; Jäckel, N.; Tekeli, M. C.; Aslan, M.; Suss, M. E.; Presser, V., MXene as a novel intercalation-type pseudocapacitive cathode and anode for capacitive deionization. J. Mater. Chem. A 2016, 4 (47), 18265-18271. 
19. Anasori, B.; Lukatskaya, M. R.; Gogotsi, Y., 2D metal carbides and nitrides (MXenes) for energy storage. Nat. Rev. Mater. 2017, 2, 16098.

20. Levi, M. D.; Lukatskaya, M. R.; Sigalov, S.; Beidaghi, M.; Shpigel, N.; Daikhin, L.; Aurbach, D.; Barsoum, M. W.; Gogotsi, Y., Solving the Capacitive Paradox of 2D MXene using Electrochemical Quartz-Crystal Admittance and In Situ Electronic Conductance Measurements. Adv. Energy Mater. 2015, 5 (1), 1400815.

21. Brousse, T.; Bélanger, D.; Long, J. W., To be or not to be pseudocapacitive? J. Electrochem. Soc. 2015, 162 (5), A5185-A5189.

22. Conway, B. E., Transition from "Supercapacitor" to "Battery" Behavior in Electrochemical Energy Storage. J. Electrochem. Soc. 1991, 138 (6), 1539-1548.

23. Bandaru, P. R.; Yamada, H.; Narayanan, R.; Hoefer, M., Charge transfer and storage in nanostructures. Mater. Sci. Eng. R 2015, 96, 1-69.

24. Salanne, M.; Rotenberg, B.; Naoi, K.; Kaneko, K.; Taberna, P. L.; Grey, C. P.; Dunn, B.; Simon, P., Efficient storage mechanisms for building better supercapacitors. Nat. Energy 2016, 1, 16070.

25. Biesheuvel, P. M.; Porada, S.; Levi, M.; Bazant, M. Z., Attractive forces in microporous carbon electrodes for capacitive deionization. J. Solid State Electrochem. 2014, 18 (5), 1365-1376.

26. Prehal, C.; Koczwara, C.; Jäckel, N.; Schreiber, A.; Burian, M.; Amenitsch, H.; Hartmann, M. A.; Presser, V.; Paris, O., Quantification of ion confinement and desolvation in nanoporous carbon supercapacitors with modelling and in situ X-ray scattering. Nat. Energy 2017, 2 (3), 16215.

27. He, F.; Biesheuvel, P. M.; Bazant, M. Z.; Hatton, T. A., Theory of water treatment by capacitive deionization with redox active porous electrodes. Water Res. 2018.

28. Porada, S.; Shrivastava, A.; Bukowska, P.; Biesheuvel, P. M.; Smith, K. C., Nickel Hexacyanoferrate Electrodes for Continuous Cation Intercalation Desalination of Brackish Water. Electrochim. Acta 2017, 255, 369-378.

29. Smith, K. C.; Dmello, R., Na-lon Desalination (NID) Enabled by Na-Blocking Membranes and Symmetric Na-Intercalation: Porous-Electrode Modeling. J. Electrochem. Soc. 2016, 163 (3), A530A539.

30. Lee, J.; Kim, S.; Yoon, J., Rocking Chair Desalination Battery Based on Prussian Blue Electrodes. ACS Omega 2017, 2 (4), 1653-1659.

31. Pasta, M.; Wessells, C. D.; Cui, Y.; La Mantia, F., A Desalination Battery. Nano Lett. 2012, 12 (2), 839-843.

32. Kim, S.; Yoon, H.; Shin, D.; Lee, J.; Yoon, J., Electrochemical selective ion separation in capacitive deionization with sodium manganese oxide. J. Colloid Interface Sci. 2017, 506, 644-648.

33. Nam, D.-H.; Choi, K.-S., Bismuth as a New Chloride-Storage Electrode Enabling the Construction of a Practical High Capacity Desalination Battery. J. Am. Chem. Soc. 2017, 139 (32), 11055-11063.

34. Hope, M. A.; Forse, A. C.; Griffith, K. J.; Lukatskaya, M. R.; Ghidiu, M.; Gogotsi, Y.; Grey, C. P., NMR reveals the surface functionalisation of $\mathrm{Ti}_{3} \mathrm{C}_{2} \mathrm{MXene}$. Physical chemistry chemical physics : PCCP 2016, 18 (7), 5099-5102.

35. Alhabeb, M.; Maleski, K.; Anasori, B.; Lelyukh, P.; Clark, L.; Sin, S.; Gogotsi, Y., Guidelines for Synthesis and Processing of 2D Titanium Carbide ( $\left.\mathrm{Ti}_{3} \mathrm{C}_{2} \mathrm{~T}_{x} \mathrm{MXene}\right)$. Chem. Mater. 2017, 29 (18), 76337644.

36. Placke, T.; Bieker, P.; Lux Simon, F.; Fromm, O.; Meyer, H.-W.; Passerini, S.; Winter, M., Dualion Cells Based on Anion Intercalation into Graphite from Ionic Liquid-Based Electrolytes. zpch 2012, $226(5-6), 391$.

37. Fan, H.; Qi, L.; Wang, H., Hexafluorophosphate anion intercalation into graphite electrode from methyl propionate. Solid State lonics 2017, 300, 169-174.

38. Zhang, X.; Zhang, Z.; Zhou, Z., MXene-based materials for electrochemical energy storage. J. Energy Chem. 2018, 27 (1), 73-85.

39. Liang, X.; Garsuch, A.; Nazar, L. F., Sulfur Cathodes Based on Conductive MXene Nanosheets for High-Performance Lithium-Sulfur Batteries. Angew. Chem., Int. Ed. 2015, 54 (13), 3907-3911.

40. Bonaccorso, F.; Colombo, L.; Yu, G.; Stoller, M.; Tozzini, V.; Ferrari, A. C.; Ruoff, R. S.; Pellegrini, V., Graphene, related two-dimensional crystals, and hybrid systems for energy conversion and storage. Science 2015, 347 (6217), 1246501. 
41. Zhong, Y.; Xia, X.; Shi, F.; Zhan, J.; Tu, J.; Fan, H. J., Transition Metal Carbides and Nitrides in Energy Storage and Conversion. Adv. Sci. 2016, 3 (5), 1500286.

42. Liu, G.; Shen, J.; Liu, Q.; Liu, G.; Xiong, J.; Yang, J.; Jin, W., Ultrathin two-dimensional MXene membrane for pervaporation desalination. J. Membr. Sci. 2018, 548, 548-558.

43. Ding, L.; Wei, Y.; Wang, Y.; Chen, H.; Caro, J.; Wang, H., A Two-Dimensional Lamellar Membrane: MXene Nanosheet Stacks. Angew. Chem., Int. Ed. 2017, 56 (7), 1825-1829.

44. Ren, C. E.; Hatzell, K. B.; Alhabeb, M.; Ling, Z.; Mahmoud, K. A.; Gogotsi, Y., Charge- and SizeSelective Ion Sieving Through $\mathrm{Ti}_{3} \mathrm{C}_{2} \mathrm{~T}_{x}$ MXene Membranes. J. Phys. Chem. Lett. 2015, 6 (20), 4026-31.

45. Fard, A. K.; McKay, G.; Chamoun, R.; Rhadfi, T.; Preud'Homme, H.; Atieh, M. A., Barium Removal from Synthetic Natural and Produced Water using MXene as Two Dimensional (2-D) Nanosheet Adsorbent. Chem. Eng. J. 2017, 317, 331-342.

46. Zhang, Q.; Teng, J.; Zou, G.; Peng, Q.; Du, Q.; Jiao, T.; Xiang, J., Efficient phosphate sequestration for water purification by unique sandwich-like MXene/magnetic iron oxide nanocomposites. Nanoscale 2016, 8 (13), 7085-7093.

47. Ghidiu, M.; Lukatskaya, M. R.; Zhao, M.-Q.; Gogotsi, Y.; Barsoum, M. W., Conductive twodimensional titanium carbide "clay" with high volumetric capacitance. Nature 2014, 516 (7529), 78-81. 48. Dahlqvist, M.; Lu, J.; Meshkian, R.; Tao, Q.; Hultman, L.; Rosen, J., Prediction and synthesis of a family of atomic laminate phases with Kagomé-like and in-plane chemical ordering. Sci. Adv. 2017, 3 (7), e1700642.

49. Tao, Q.; Dahlqvist, M.; Lu, J.; Kota, S.; Meshkian, R.; Halim, J.; Palisaitis, J.; Hultman, L.; Barsoum, M. W.; Persson, P. O. A.; Rosen, J., Two-dimensional $\mathrm{Mo}_{1.33} \mathrm{C}$ MXene with divacancy ordering prepared from parent 3D laminate with in-plane chemical ordering. Nat. Commun. 2017, 8, 14949.

50. Weingarth, D.; Zeiger, M.; Jäckel, N.; Aslan, M.; Feng, G.; Presser, V., Graphitization as a universal tool to tailor the potential-dependent capacitance of carbon supercapacitors. Adv. Energy Mater. 2014, 4 (13), 1400316.

51. Aslan, M.; Zeiger, M.; Jäckel, N.; Grobelsek, I.; Weingarth, D.; Presser, V., Improved capacitive deionization performance of mixed hydrophobic/hydrophilic activated carbon electrodes. J. Phys.: Condens. Matter 2016, 28 (11), 114003.

52. Jäckel, N.; Rodner, M.; Schreiber, A.; Jeongwook, J.; Zeiger, M.; Aslan, M.; Weingarth, D.; Presser, $\mathrm{V}$., Anomalous or regular capacitance? The influence of pore size dispersity on double-layer formation. J. Power Sources 2016, 326 (1), 660-671.

53. He, D.; Wong, C. E.; Tang, W.; Kovalsky, P.; Waite, T. D., Faradaic Reactions in Water Desalination by Batch-Mode Capacitive Deionization. Environ. Sci. Technol. Lett. 2016, 3 (5), 222-226.

54. Gao, X.; Porada, S.; Omosebi, A.; Liu, K.-L.; Biesheuvel, P. M.; Landon, J., Complementary surface charge for enhanced capacitive deionization. Water Res. 2016, 92, 275-82.

55. Lee, J.; Srimuk, P.; Aristizabal, K.; Kim, C.; Choudhury, S.; Nah, Y. C.; Mücklich, F.; Presser, V., Pseudocapacitive desalination of brackish water and seawater with vanadium-pentoxide-decorated multiwalled carbon nanotubes. ChemSusChem 2017, 10 (18), 3611-3623.

56. Kim, C.; Srimuk, P.; Lee, J.; Aslan, M.; Presser, V., Semi-continuous capacitive deionization using multi-channel flow stream and ion exchange membranes. Desalination 2018, 425 (1), 104-110.

57. Elimelech, M.; Phillip, W. A., The Future of Seawater Desalination: Energy, Technology, and the Environment. Science 2011, 333 (6043), 712-717.

58. Kim, T.; Yoon, J., CDI ragone plot as a functional tool to evaluate desalination performance in capacitive deionization. RSC Adv. 2015, 5 (2), 1456-1461.

59. Centeno, T. A.; Sereda, O.; Stoeckli, F., Capacitance in carbon pores of 0.7 to $15 \mathrm{~nm}$ : a regular pattern. Physical chemistry chemical physics : PCCP 2011, 13 (27), 12403-6.

60. Dykstra, J. E.; Dijkstra, J.; van der Wal, A.; Hamelers, H. V. M.; Porada, S., On-line method to study dynamics of ion adsorption from mixtures of salts in capacitive deionization. Desalination 2016, $390,47-52$.

61. Zhao, R.; van Soestbergen, M.; Rijnaarts, H. H. M.; van der Wal, A.; Bazant, M. Z.; Biesheuvel, P. M., Time-dependent ion selectivity in capacitive charging of porous electrodes. J. Colloid Interface Sci. 2012, 384 (1), 38-44. 


\section{Figures}
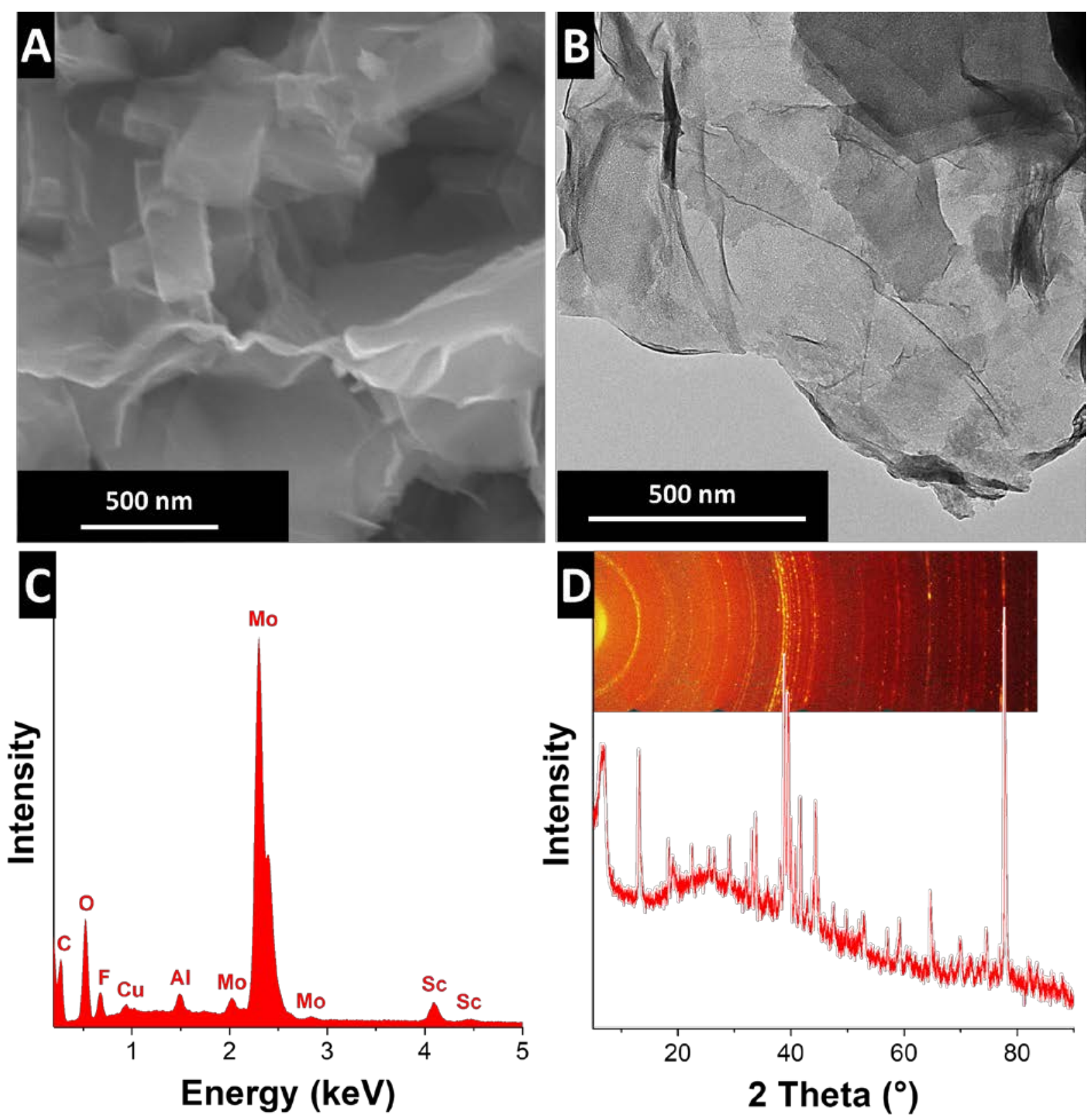

Figure 1: Characterization of $\mathrm{Mo}_{1.33} \mathrm{C}$ MXene used as electrode material: Scanning electron micrograph (A), transmission electron micrograph of (B), energy-dispersive X-ray spectrum (C), and X-ray diffractogram and corresponding two-dimensional scattering picture (D). 



Potential vs. Ag/AgCl (V)


Figure 2: Electrochemical characterization of binder-free $\mathrm{Mo}_{1.33} \mathrm{C}-\mathrm{CNT}$ electrode in $1 \mathrm{M} \mathrm{NaCl}$. (A) Cyclic voltammogram at $5 \mathrm{mV} / \mathrm{s}$, (B) specific capacitance vs. specific current, (C) capacitance retention at limiting positive and negative potential, (D) cyclic voltammogram of symmetrical full cell at $5 \mathrm{mV} / \mathrm{s}$, (E) specific capacitance vs. specific current of symmetrical full cell, and (F) potential development of the positive electrode, negative electrode, and potential at zero cell voltage. 

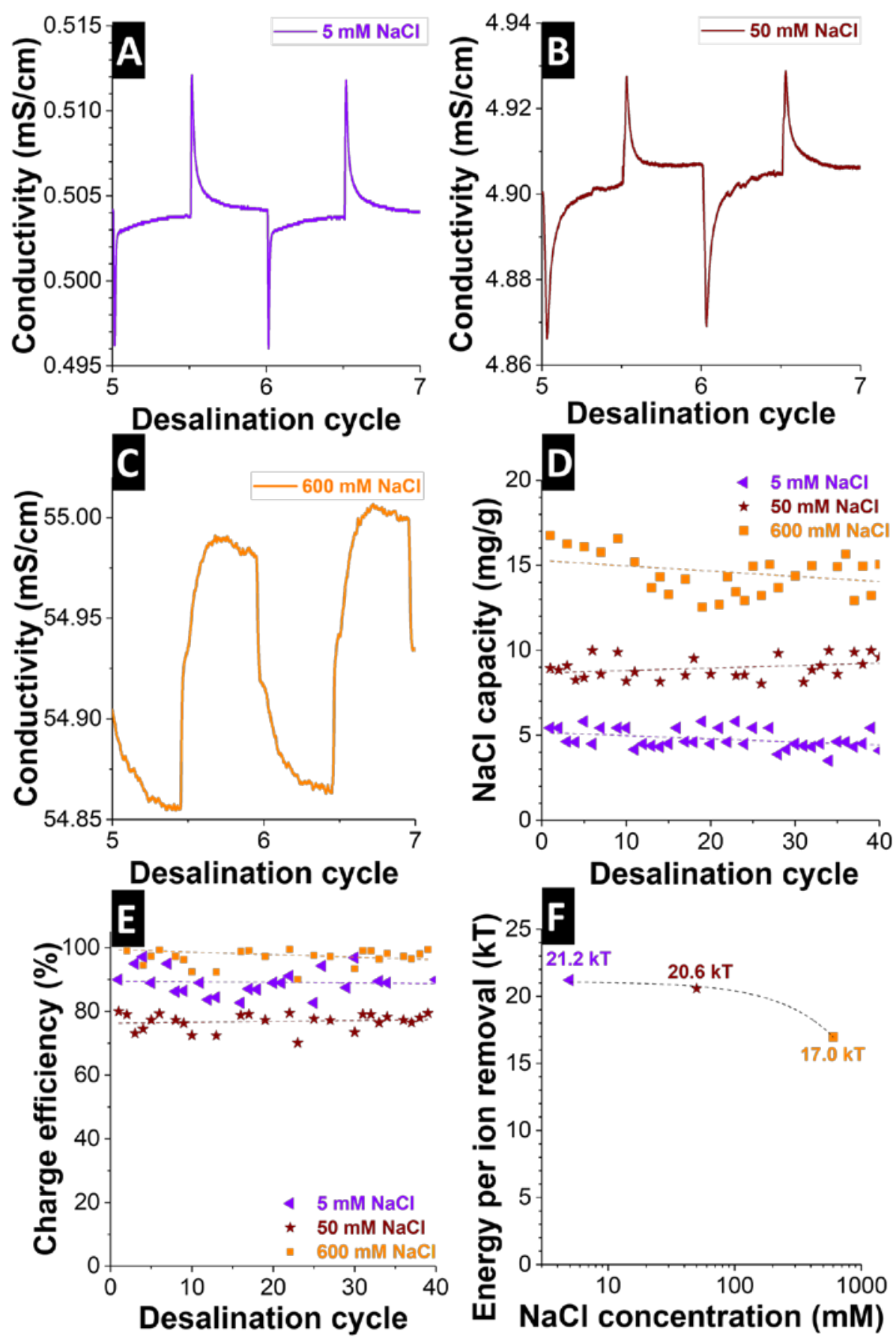

Figure 3: Constant voltage desalination with $\mathrm{Mo}_{1.33} \mathrm{C}-\mathrm{CNT}$ at $0.8 \mathrm{~V}$ at $5 \mathrm{mM}, 50 \mathrm{mM}$, or $600 \mathrm{mM} \mathrm{NaCl}$. (A-C) Conductivity profiles of effluent stream leaving the desalination cell. (D) $\mathrm{NaCl}$ removal capacity. (E) Charge efficiency. (F) Energy consumption per removed ion. 

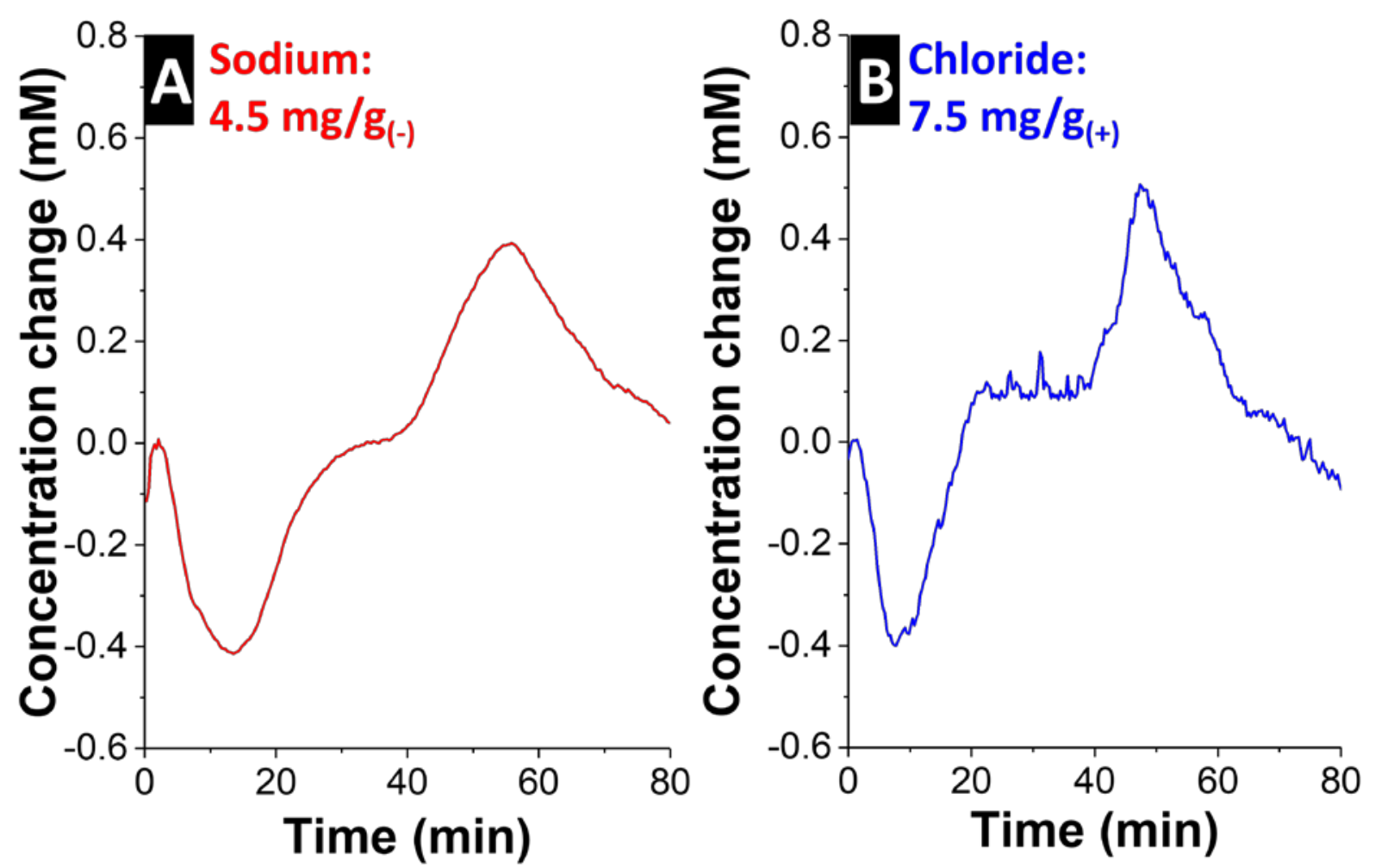

Figure 4: Concentration profiles measured with ICP-OES in $5 \mathrm{mM} \mathrm{NaCl}$ aqueous solution. The cation uptake capacity $(A)$ is normalized to the mass of the negative electrode $(-)$ and the anion uptake capacity (B) is normalized to the mass of the positive electrode $(+)$. 


\section{Tables}

Table 1. Elemental analysis of $\mathrm{Mo}_{1.33} \mathrm{C}$ MXene via EDX.

\begin{tabular}{|l|c|c|c|c|c|c|}
\hline Mass\% & C & O & F & Al & Sc & Mo \\
\hline Mo $_{1.33} \mathrm{C}$ & 12.1 & 8.2 & 1.3 & 7.9 & 5.8 & 64.6 \\
\hline
\end{tabular}

Table 2. Comparison of desalination capacity and desalination rate.

\begin{tabular}{|l|c|c|c|c|c|}
\hline Electrode material & $\begin{array}{c}\text { Cell } \\
\text { voltage } \\
(\mathbf{V})\end{array}$ & $\begin{array}{c}\text { Salt removal } \\
\text { capacity } \\
(\mathbf{m g} / \mathbf{g})\end{array}$ & $\begin{array}{c}\text { Salt removal } \\
\text { rate } \\
(\boldsymbol{\mu g} / \mathbf{g} / \mathbf{s})\end{array}$ & $\begin{array}{c}\text { NaCl } \\
\text { concentration } \\
(\mathbf{m M})\end{array}$ & Reference \\
\hline Activated carbon (YP-80F) & 0.8 & 15 & 6.5 & 5 & 15 \\
\hline Activated carbon (MSP-20) & 1.2 & 23.6 & 19 & 10 & 58 \\
\hline $\mathrm{MoS}_{2}$-CNT & 0.8 & 25 & 7 & 500 & 15 \\
\hline $\mathrm{MoS}_{2}$-CNT & 0.8 & 9 & 2.5 & 5 & 15 \\
\hline $\mathrm{Ti}_{3} \mathrm{C}_{2} \mathrm{MXene}$ & 1.2 & 13 & 16 & 5 & 18 \\
\hline $\mathrm{Ti}_{3} \mathrm{C}_{2} \mathrm{MXene}$ & 1.2 & 13 & 16 & 5 & 18 \\
\hline $\mathrm{Mo}_{1.33} \mathrm{C} \mathrm{MXene}$ & 0.8 & 5 & 2.1 & 5 & This work \\
\hline $\mathrm{Mo}_{1.33} \mathrm{C} \mathrm{MXene}$ & 0.8 & 15 & 5.9 & 600 & This work \\
\hline
\end{tabular}


Table of content graphic

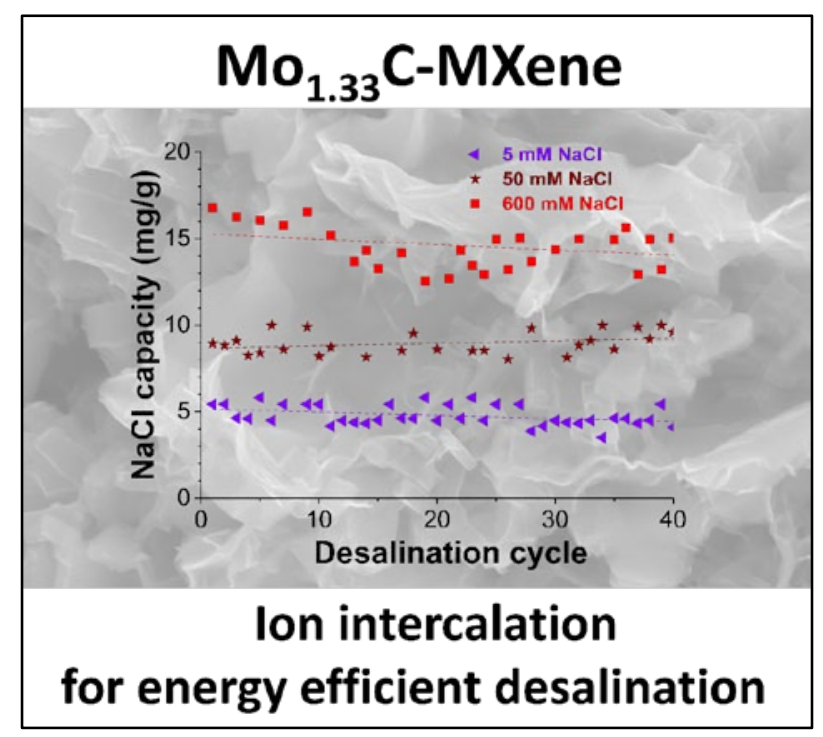

Molybdenum carbide MXene is an effective electrode material for sustainable water desalination even at high molar strength $(600 \mathrm{mM} \mathrm{NaCl})$. 
Supporting Information

\section{Two-dimensional molybdenum carbide (MXene) with divacancy ordering for brackish and sea water desalination via cation and anion intercalation}

\footnotetext{
P. Srimuk, ${ }^{\mathrm{a}, \mathrm{b}}$ J. Halim, ${ }^{\mathrm{b}}$ J. Lee, ${ }^{\mathrm{a}, \mathrm{c}} \mathrm{Q}$. Tao, ${ }^{\mathrm{b}}$ J. Rosen, $^{\mathrm{b}, *}$ and V. Presser ${ }^{\mathrm{a}, \mathrm{c}, *}$

a INM - Leibniz Institute for New Materials, Campus D22, 66123 Saarbrücken, Germany

b Thin Film Physics, Department of Physics, Chemistry and Biology (IFM), Linköping University, SE-581 83 Linköping, Sweden

c Department of Materials Science and Engineering, Saarland University, 66123 Saarbrücken, Germany

* Corresponding authors' eMail: johanna.rosen@liu.se (JR)\&volker.presser@leibniz-inm.de (VP)
}

The supporting information includes 2 figures. 


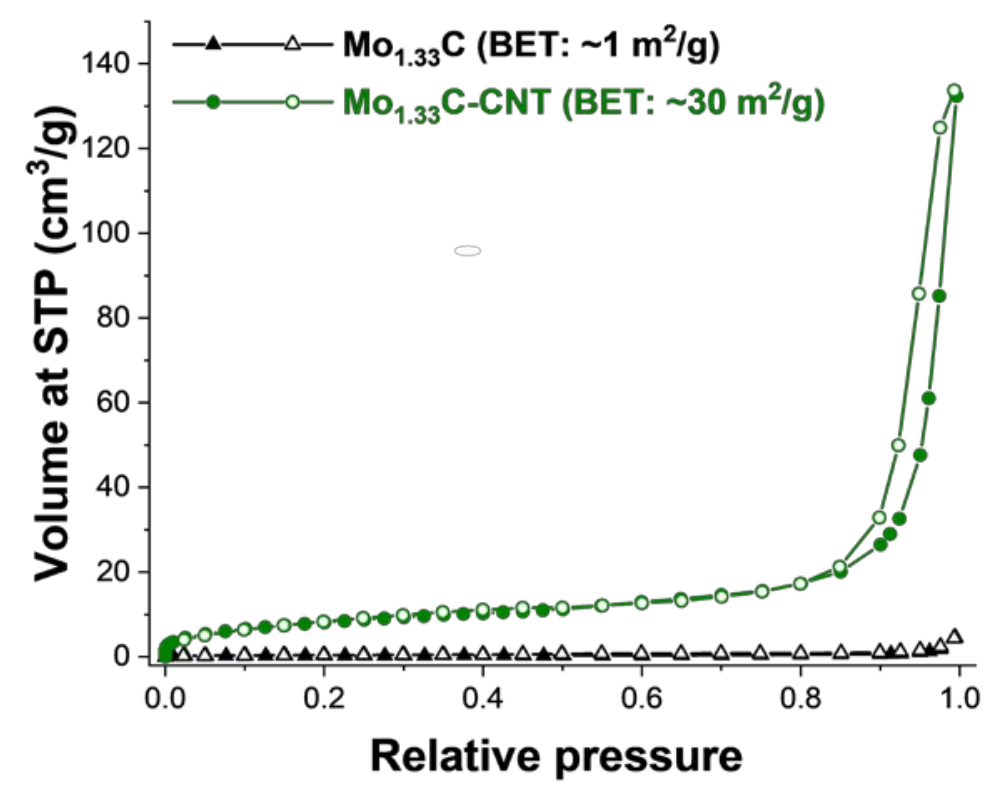

Fig. S1: Nitrogen gas sorption isotherm of $\mathrm{Mo}_{1.33} \mathrm{C}$ and $\mathrm{Mo}_{1.33} \mathrm{C}-\mathrm{CNT}$.
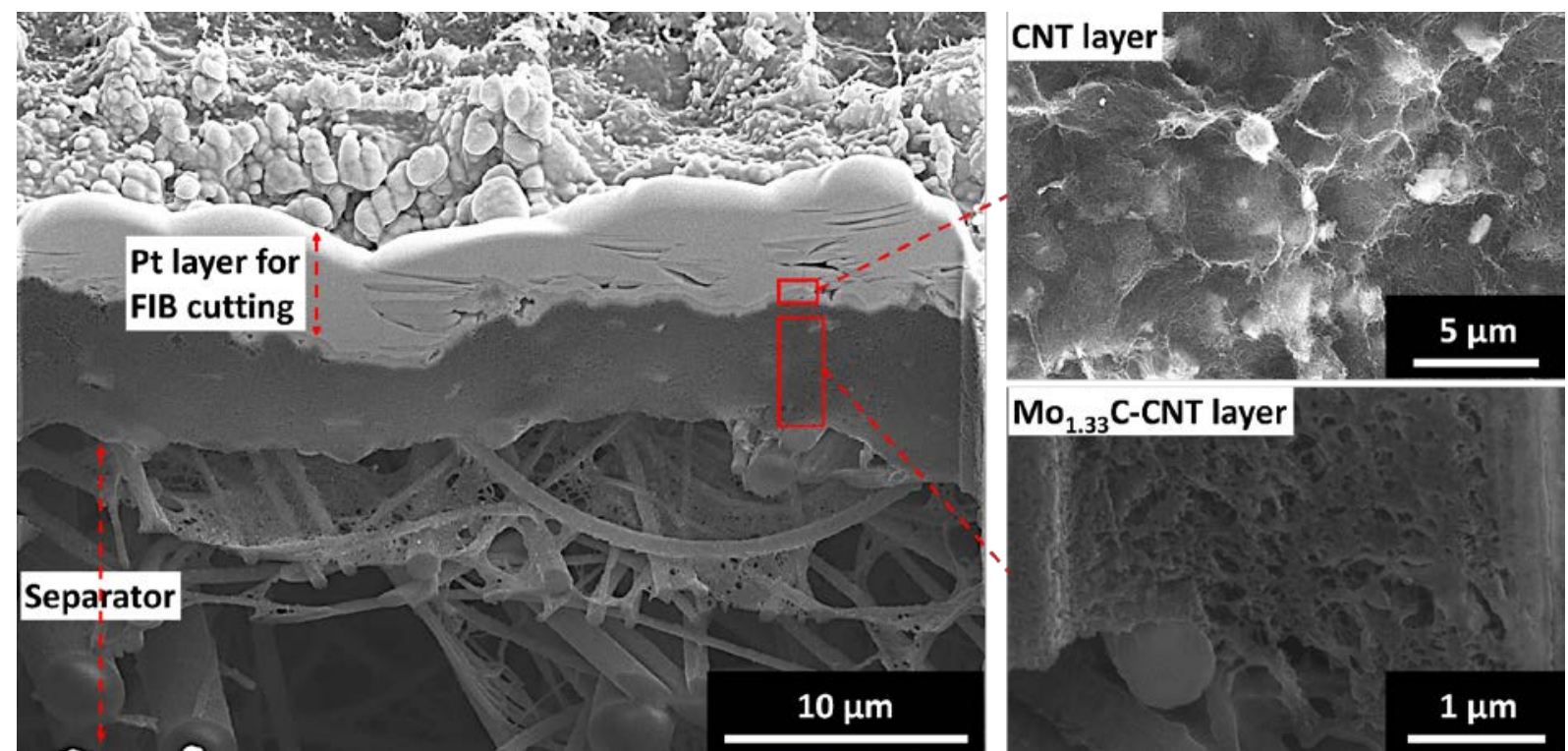

$\mathrm{Mo}_{1.33} \mathrm{C}$-CNT layer

Fig. S2: Cross-section scanning electron micrograph of binder-free $\mathrm{Mo}_{1.33} \mathrm{C}-\mathrm{CNT}$ electrode prepared via focussed ion beam (FIB). 